Model Pengelolaan dan ... (Eva P. P. dan Martin R. P. H.)

\title{
MODEL PENGELOLAAN DAN RENCANA IMPLEMENTASI MANAJEMEN RISIKO PADA PT. PERDANA KARYA PERKASA, TBK
}

\author{
Eva Phasa Purpadita \\ Program Studi S2 MM Wijawiyata Manajemen \\ Sekolah Tinggi Manajemen PPM \\ Martin Ronald Pardomuan Hutajulu \\ Program Studi S2 MM Wijawiyata Manajemen \\ Sekolah Tinggi Manajemen PPM \\ Aries Heru Prasetyo \\ Sekolah Tinggi Manajemen PPM
}

\begin{abstract}
Ada fenomena yang menarik dan unik yang dimiliki industri konstruksi, yaitu pertama, industri jasa konstruksi adalah sebuah industri yang tergolong berisiko besar tetapi banyak peminatnya, hal ini dapat dicermati dengan demikian ketatnya kompetisi. Kedua, industri konstruksi merupakan sebuah industri yang tidak sekedar berorientasi pada produk jadi, sebagaimana pada industri lain, tetapi berorientasi pada proses. Terkait dengan hal tersebut PKP yang salah satu unit bisnisnya bergerak dalam usaha jasa konstruksi minyak dan gas, yaitu kegiatan jasa usaha layanan untuk penanganan pekerjaan bangunan atau konstruksi atau wujud fisik lainnya dalam menunjang kegiatan usaha migas. Bila ditinjau dari berbagai aspek jelas sarat dengan risiko bagi pihak yang terlibat di dalamnya. Dalam menerima dan mengelola risiko tersebut maka diperlukan penerapan manajemen risiko, yang tujuannya untuk meminimalisasi potensi risiko kerugian pada perusahaan. Dalam penelitian, teridentifikasi sebanyak 27 risiko operasional (terdiri dari 17 risiko kategori low; 9 risiko kategori medium; 1 risiko kategori high) dan sebanyak 118 risiko K3 (terdiri dari 84 risiko kategori low; 29 risiko kategori medium; 5 risiko kategori high). Dan dari semua temuan risiko tertinggi yang teridentifikasi, diperlukan penanganan lebih lanjut dengan membuat rencana penanganan risiko
\end{abstract}

Keywords:

Risiko, Manajemen Risiko, Konstruksi, Industri Migas 


\section{PENDAHULUAN}

PT. Perdana Karya Perkasa, Tbk (PKP) adalah perusahaan yang bergerak dibidang penyewaaan alat berat, energi pertambangan dan jasa konstruksi migas.

Industri jasa konstruksi adalah sebuah industri yang tergolong berisiko besar tetapi banyak peminatnya, hal ini dapat dicermati dengan demikian ketatnya kompetisi. Industri konstruksi merupakan sebuah industri yang tidak sekedar berorientasi pada produk jadi, sebagaimana pada industri lain, tetapi berorientasi pada proses.

Terkait dengan hal tersebut PKP yang salah satu unit bisnisnya bergerak dalam usaha jasa konstruksi minyak dan gas, yaitu kegiatan jasa usaha layanan untuk penanganan pekerjaan bangunan atau konstruksi atau wujud fisik lainnya dalam menunjang kegiatan usaha migas. Bila ditinjau dari berbagai aspek jelas sarat dengan risiko bagi pihak yang terlibat di dalamnya. Banyak masalah internal dihasilkan sendiri oleh perusahaan dan sebenarnya ada dalam kendali organisasi perusahaan. Masalah ini biasanya berhubungan dengan lemahnya manajemen perusahaan. Sehingga masalah manajemen adalah satu-satunya faktor terbesar dibalik banyaknya kegagalan perusahaan.

Dengan melihat kenyataan ini maka dalam menjalankan bisnis jasa konstruksi dalam bidang pelaksanaan (kontraktor) pada perusahaan jasa konstruksi swasta dan BUMN harus mampu menganalisis kualitas manajemen perusahaan agar dapat meningkatkan kinerja perusahaannya.

Secara umum PKP akan menghadapi risiko yang mempengaruhi hasil kegiatan usaha jasa konstuksi migas. Dalam menerima dan mengelola risiko tersebut maka diperlukan penerapan manajemen risiko, yang tujuannya untuk meminimalisasi potensi risiko kerugian pada perusahaan.

Diketahui bahwa PKP belum memiliki divisi manajemen risiko, untuk kondisi saat ini hanya ada divisi Kesehatan Keselamatan Karyawan (K3) untuk menangani operasional di lapangan saja, namun tidak untuk operasional keseluruhan sejak awal proses bisnis PKP, walaupun sampai saat ini belum pernah ada kejadian yang sangat merugikan, hal ini harus diwaspadai agar ketika nanti kemungkinan terjadi kerugian, PKP sudah siap untuk menghadapinya.

Perumusan masalah pada penelitian ini, adalah belum adanya bentuk manajemen risiko operasional serta implementasinya, sehingga dapat dirumuskan sebagai berikut:

1. Bagaimanakah bentuk rancangan manajemen risiko operasional yang akan ditujukan untuk PKP?

2. Bagaimanakah bentuk rencana implementasi manajemen risiko pada PKP?

\section{TINJAUAN PUSTAKA}

\subsection{Manajemen Risiko}

Secara sederhana pengertian manajemen risiko organisasi adalah pelaksanaan fungsi-fungsi manajemen dalam penanggulangan risiko, terutama risiko yang dihadapi oleh organisasi atau perusahaan, keluarga dan masyarakat. Jadi mencakup kegiatan merencanakan, mengorganisir, menyusun, memimpin/mengkoordinir dan mengawasi (termasuk mengevaluasi) program penanggulangan risiko (Dr. Mamduh M. Hanafi, 2006).

Manajemen risiko adalah seperangkat kebijakan, prosedur yang lengkap, yang dipunyai organisasi, untuk mengelola, memonitor, dan mengendalikan eksposur organisasi terhadap risiko (Kountur, 2004, hal. 18). 
Manajemen risiko korporat terintegrasi, atau ERM (Enterprise Risk Management) merupakan proses terstruktur dan sistematis dalam mengidentifikasi, mengukur, memetakan, mengembangkan alternatif penanganan risiko, dan dalam memonitor dan mengendalikan implementasi penanganan risiko (Djohanputro, 2008, hal. 43).

\subsection{ISO 31000 Proses Manajemen \\ Risiko}

Proses manajemen risiko adalah penerapan secara sistematik kebijakan manajemen, prosedur dan praktik manajemen dalam pelaksanaan tugas untuk melakukan komunikasi dan konsultasi; menetapkan konteks; melakukan asesmen risiko yang meliputi identifikasi; analisis dan evaluasi risiko; kemudian perlakuan risiko, dan diakhiri dengan pemantauan dan pengkajian risiko. Proses manajemen risiko secara singkat adalah penerapan kerangka kerja manajemen risiko pada tiap-tiap jenis risiko yang secara spesifik mempunyai karakter yang berbeda-beda sesuai dengan konteksnya. Walaupun penerapan proses manajemen risiko khas untuk masing-masing risiko, tetapi secara metodologis, penerapannya sesuai dengan sistem yang digambarkan pada Gambar 1. di bawah ini.

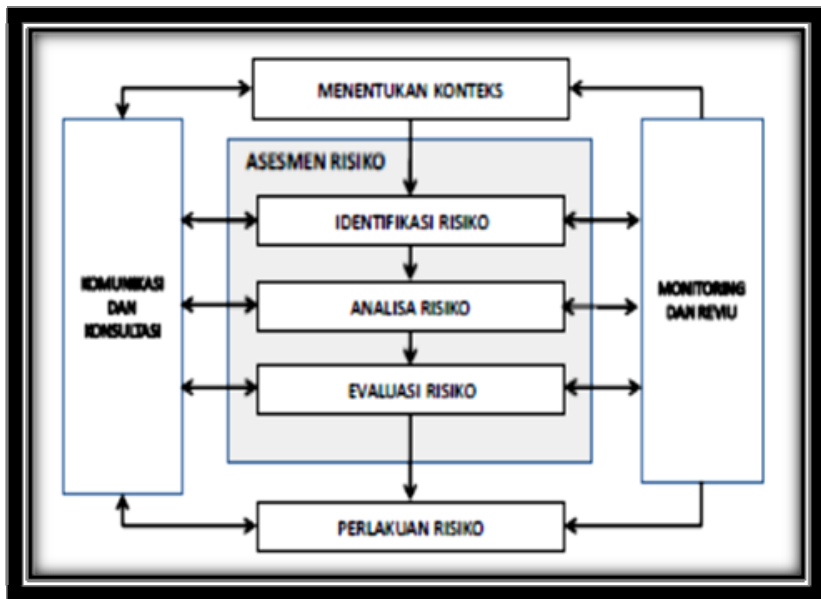

sumber : Leo J. (2010) Gambar 1.

Proses Manajemen Risiko

\subsubsection{Memahami Organisasi dan Konteksnya}

Sebelum mulai merencanakan dan menerapkan kerangka kerja manajemen risiko,sangat penting untuk memahami kondisi dan sifat organisasi serta konteks internal maupun eksternalnya. Hal ini sangat penting karena menentukan bentuk rencana dari kerangka kerja tersebut. a. Konteks eksternal

Konteks eksternal adalah lingkungan eksternal di mana organisasi tersebut mengupayakan pencapaian sasaran yang ditetapkannya. Memahami konteks eksternal penting untuk memastikan siapa saja pemangku kepentingan eksternal; apa saja kepentingan dan sasarannya sehingga dapat dipertimbangkan dalam menentukan kriteria risiko. 
b. Konteks Internal

Konteks internal adalah lingkungan internal di mana organisasi tersebut mengupayakan pencapaian sasaran yang ditetapkannya. Proses manajemen risiko haruslah diselaraskan dengan budaya, proses, dan struktur organisasi. Konteks internal adalah segala sesuatu di dalam organisasi yang dapat memengaruhi cara organisasi dalam mengelola risiko.

\subsubsection{Asesmen Risiko}

Berikut langkah-langkah dalam asesmen risiko:

a. Identifikasi Risiko

Pada tahap ini dilakukan proses identifikasi apa saja risiko yang dapat dihadapi oleh perusahaan. Dengan melakukan indentifikasi, diperolehlah sekumpulan informasi tentang kejadian risiko, informasi penyebab risiko bahkan informasi mengenai dampak apa saja yang bisa ditimbulkan dari risiko tersebut.

b. Analisis Risiko

Pada tahap ini risiko yang telah teridentifikasi akan diukur melalui dua faktor yaitu kuantitas (dampak, nilai, atau eksposur) risiko dan kualitas risiko (seberapa sering atau frekuensi risiko). Data historis dapat dijadikan acuan untuk melakukan pengukuran risiko.

1. Kemungkinan

Kemungkinan sering dinyatakan dengan probabilitas, yaitu suatu angka di antara 0 dan 1 . Angka 0 menyatakan bahwa kejadian yang dimaksud tidak mungkin terjadi. Sebaliknya angka 1 menyatakan bahwa hal tersebut pasti terjadi. Akan tetapi, tidak ada yang absolut sehingga ketidakpastian tersebut dinyatakan dalam angka 0 dan 1, misalnya angka terkecil 0.01 dan angka maksimum 0.90. Akan tetapi, untuk dapat menentukan berapa angka probabilitas yang tepat tidaklah sederhana. Memerlukan proses statistik dan model matematika untuk mengetahui pola distribusinya.

2. Dampak

Besarnya dampak risiko yang dapat ditolerir oleh suatu organisasi harus dirumuskan secara jelas. Ini dikenal dengan istilah selera risiko atau toleransi risiko (risk appetite). Besaran-besaran ini sepenuhnya menjadi kewenangan manajemen puncak organisasi dan bagi unit kerja adalah pimpinan unit kerjanya. Panduan besarnya dampak yang akan digunakan dalam analisis risiko ini biasanya diterapkan dalam bentuk tabel.

Jika dianggap bahwa tingkat risiko adalah proporsional terhadap setiap komponennya, fungsi risiko pada dasarnya adalah sebuah perkalian. Secara matematis dapat ditunjukkan sebagai berikut:

Risiko $=$ Dampak $x$ Kemungkinan

c. Evaluasi Risiko

Pemeringkatan risiko merupakan kelanjutan dari tahap pengukuran risiko. Dalam arti luas, pemetaan risiko pada prinsipnya merupakan penyusunan risiko berdasarkan kelompok-kelompok tertentu sehingga manajemen dapat mengidentifikasi karakter dari masingmasing risiko dan menetapkan tindakan yang sesuai terhadap masing-masing risiko.

Pemeringkatan risiko berarti proses penetapan prioritas dalam penanganan risiko dari keseluruhan risiko yang berhasil diidentifikasi, hanya untuk risiko yang berhasil diidentifikasi. Ada risiko-risiko yang perlu mendapat perhatian khusus tetapi ada pula risiko yang dapat diabaikan. Oleh karena itu perusahaan perlu membuat peringkat 
risiko. Tujuan dari pemeringkatan ini adalah untuk menetapkan prioritas risiko berdasarkan kepentingannya bagi perusahaan.

\subsubsection{Model Pengelolaan Risiko}

Mengelola risiko dengan menentukan perlakuan risiko. Hasil dari evaluasi risiko adalah suatu daftar yang berisi peringkat risiko yang memerlukan perlakuan lebih lanjut. Manajemen organisasi harus melakukan kajian dan menentukan jenis serta bentuk perlakuan risiko yang diperlukan. Perlakuan risiko ini tidak harus bersifat khusus untuk satu situasi tertentu, juga tidak harus berlaku umum. Ini berarti setiap risiko memerlukan bentuk perlakuan yang khas untuk setiap risiko itu sendiri.

Ada beberapa strategi dalam berhadapan dengan risiko, yang dapat mengurangi atau mengendalikan risiko. Yang umum digunakan adalah sebagai berikut:

a. Avoidance (menghindari)

Menghindari risiko, hasil dari terjadinya risiko sudah diketahui dengan pasti, sehingga dapat mengambil langkah lain untuk menghindari risiko tersebut terjadi.

b. Transference (memindahkan atau berbagi)

Teknik yang digunakan untuk memindahkan atau berbagi risiko dan konsekuensi kepada pihak ketiga.

c. Mitigation (mitigasi)

Teknik ini mencoba untuk mengurangi kemungkinan dan dampak jika peristiwa tersebut muncul, sampai kepada tingkat yang dapat diterima.

d. Acceptance (menerima)

Teknik ini adalah bersedia menerima jika peristiwa itu terjadi, karena mungkin jika peristiwa itu terjadi tidak terlalu berpengaruh terhadap perusahaan, atau perusahaan tidak dapat menghalau risiko itu terjadi, sehingga hanya menerima risiko itu saja.

\subsubsection{Komunikasi dan Konsultasi}

Komunikasi dan konsultasi yang efektif, baik internal maupun eksternal, haruslah membuahkan kejelasan bagi pihakpihak yang bertanggung jawab untuk menerapkan proses manajemen risiko dan para pemangku kepentingan terkait. Mereka harus memahami dengan baik kriteria pengambilan keputusan serta mengapa suatu tindakan perlu diambil.

Rencana komunikasi dan konsultasi hendaknya:

a. Merupakan forum untuk bertukar informasi di antara para pemangku kepentingan;

b. Tempat untuk menyampaikan pesan secara jujur, akurat, mudah dimengerti, dan didasarkan pada fakta yang ada;

c. Bermanfaat dan besar kontribusinya harus dapat dinilai.

\subsubsection{Monitor dan Review}

Manajemen perlu memastikan bahwa pelaksanaan pengelolaan risiko berjalan sesuai dengan rencana. Manajemen juga perlu memastikan bahwa model pengelolaan risiko cukup efektif. Monitor dan pengendalian bertujuan untuk memantau perkembangan terhadap kecenderungan kecenderungan berubahnya profil risiko. Perubahan ini berdampak pada pergeseran peta risiko yang otomatis pada perubahan prioritas risiko. Pengendalian yang meliputi evaluasi secara menyeluruh pelaksanaan manajemen risiko, output pelaporan yang dihasilkan olehmanajemen risiko, dan umpan balik (feedback).

Hasil monitoring dan review harus didokumentasikan dengan baik sesuai dengan kebutuhan. Harus juga dilaporkan, baik internal maupun eksternal. Ini juga merupakan bagian dalam proses kerangka manajemen risiko. 
III

\section{METODE PENELITIAN}

\section{1}

\section{Teknik Pengumpulan Data}

Dalam penelitian ini peneliti menerapkan beberapa teknik yang dapat membantu peneliti untuk mengumpulkan data-data yang dibutuhkan. Teknik-teknik pengumpulan data yang digunakan tersebut adalah:

1. Pengumpulan Data sekunder

a. Studi Pustaka

Yaitu membuat landasan teoritis dari penelitian ini. Data yang didapat berupa teori-teori yang diperoleh dari buku-buku dan literatur-literatur yang terdapat dari sumber-sumber lain.

b. Studi Dokumen

Studi dokumen adalah proses pengumpulan data yang bersumber pada catatan atau dokumen yang tersedia yang berasal dari perusahaan yang bersangkutan.

2. Pengumpulan Data Primer

a. Wawancara

Yaitu mengajukan pertanyaanpertanyaan kepada beberapa karyawan perusahaan (orang yang diberi wewenang untuk diwawancarai oleh pimpinan) berdasarkan panduan daftar pertanyaan yang telah disiapkan.

Berikut merupakan beberapa orang yang diwawancarai: Untung Haryono sebagai Direktur Keuangan; Heri Priambodo sebagai Sekretaris
Perusahaan; Sjaifur Robi sebagai Project Manager; Kepala bagian setiap divisi untuk mengisi daftar risiko yang biasa dihadapi dan kuesioner Maturity Level.

3. Maturity Level in Organizational Risk Management

Maturity Level in Organizational Risk Management merupakan metode yang digunakan untuk mengetahui tingkat maturity sebuah perusahaan dalam melakukan penerapan manajemen risiko. Metode ini menggunakan kuesioner untuk memperoleh informasi yang dibutuhkan untuk mengetahui tingkat maturity dalam penerapan manajemen risiko pada perusahaan yang dimaksud. Kuesioner yang digunakan berisikan empat indicator yang terdiri atas culture, process, experience, dan application. Tiap-tiap indicator memiliki poin-poin yang mewakili dari pertanyaan yang terdapat dalam kuesioner tersebut. Dari setiap indikator yang ada dalam kuesioner, terdapat penjelasan mengenai masingmasing ukuran yang digunakan di dalamnya. Berikut merupakan penjelasan mengenai indikator yang digunakan serta parameter pengukurannya.

\subsection{Kerangka Analisis}

Berikut merupakan kerangka analisis yang digunakan dalam penelitian ini (Gambar 2.). 


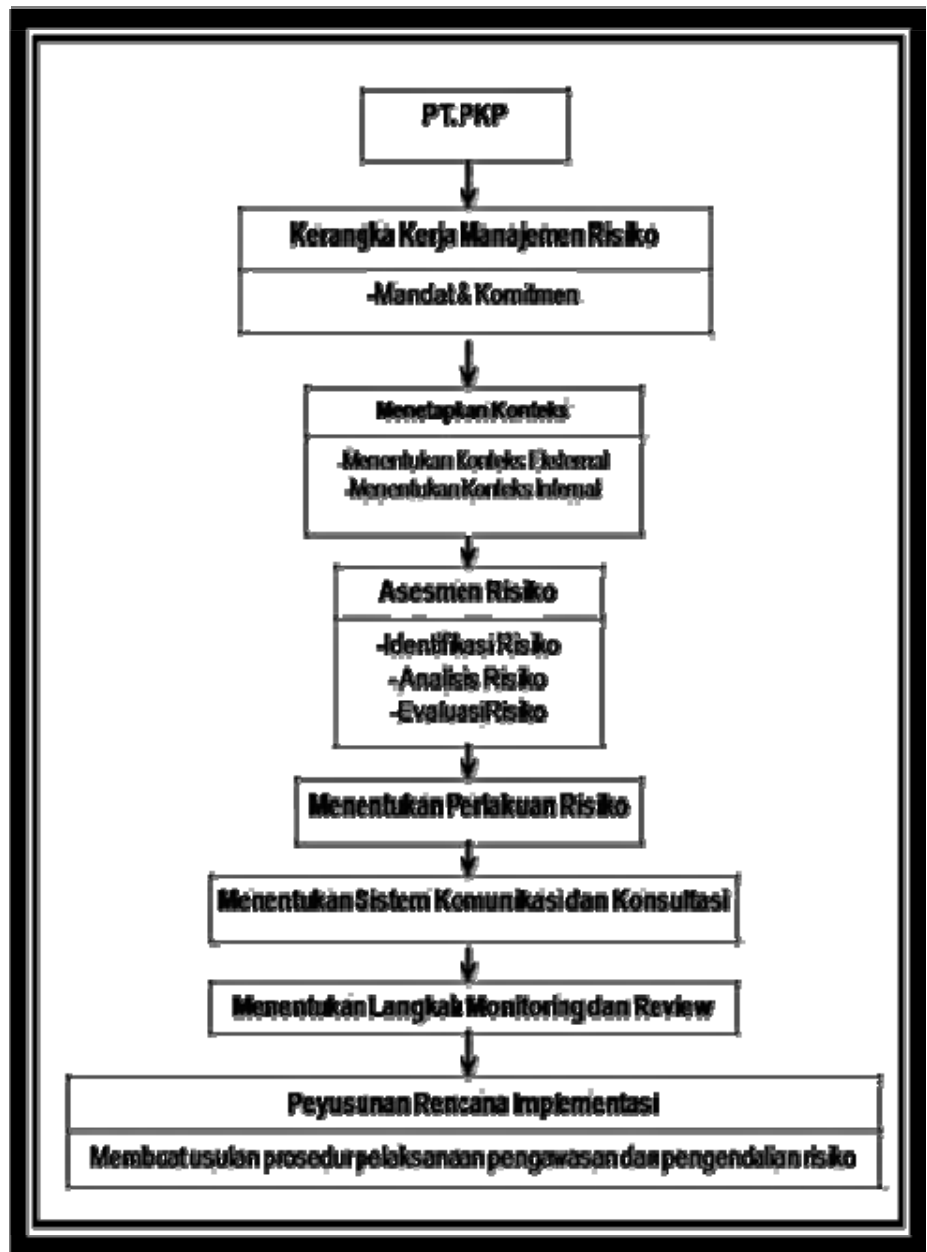

Gambar 2.

Kerangka Analisis

\section{ANALISIS DAN PEMBAHASAN}

\subsection{Penetapan Konteks}

\subsubsection{Analisis Eksternal}

Hasil analisis internal dengan metode 7s Mckinsey pada PKP, dapat dilihat bahwa system, strategy, shared vision, skill, staffing, style, dan structure tidak mengalami masalah berarti serta cenderung selaras dengan visi dan misi yang ingin dicapai oleh PKP. Dapat dikatakan selaras karena tidak ditemukannya adanya faktor-faktor yang dapat memicu kemunculan risiko-risiko yang akan membuat PKP tidak dapat mencapai tujuan yang telah direncanakan. Kemudian berdasarkan tingkat maturity dalam risk management, PKP dapat dikatakan minim dalam bentuk pengalaman manajemen risiko, tetapi jika dilihat dari sisi faktor culture, PKP memiliki nilai tertinggi dibanding faktor - faktor yang lainnya, yang menandakan PKP sudah memiliki kesadaran mengenai perlunya penerapan manajemen risiko dalam proses kerjanya. Sehingga konteks internal dalam perancangan manajemen risiko korporat ini adalah seputar pencapaian sasaran yang telah ditetapkan oleh PKP. 


\subsubsection{Analisis Internal}

Kemudian berdasarkan hasil analisis eksternal yang menggunakan metode analisis PESTEL, diketahui bahwa PKP harus siap akan kondisi pasar bebas, yaitu berkompetisi juga dengan perusahaan asing. Diikuti dengan perkembangan inovasi dari teknologi. Para pelaku usaha jasa konstruksi dalam negeri termasuk PKP harus terus meningkatkan kinerja dan kualitas sumber daya manusia (SDM) mereka, seiring membanjirnya kontraktor asing ke Indonesia.Kemudian berdadasarkan hasil analisis eksternal yang menggunakan metode analisis stakeholder, diketahui bahwa PKP memiliki tiga stakeholder utama yang memberikan pengaruh yang dominan bagi PKP dalam kaitannya dengan stakeholder, hubungan yang buruk membuat komunikasi kurang terjalin dengan baik. Jika komunikasi sudah tidak baik, maka proyek akan sulit berjalan sesuai rencana. Termasuk dengan vendor, hubungan haruslah dijalin dengan baik, karena vendor merupakan tulang punggung kontraktor dalam bekerja. Hal seperti ini dapat memicu terjadinya risiko operasional bagi PKP.

\subsection{Asesmen Risiko Operasional \\ 4.2.1 Identifikasi Risiko Operasional \\ Dalam mengidentifikasi risiko} operasional PKP kami menggunakan tahapan proses bisnis. Proses bisnis yang kami identifikasi adalah proses bisnis di unit bisnis kegiatan usaha jasa konstruksi migas. Oleh karena itu akan lebih mudah untuk mengembangkan daftar risiko yang luas dan lengkap. Kami menggunakan metode wawancara dengan kepala setiap divisi.

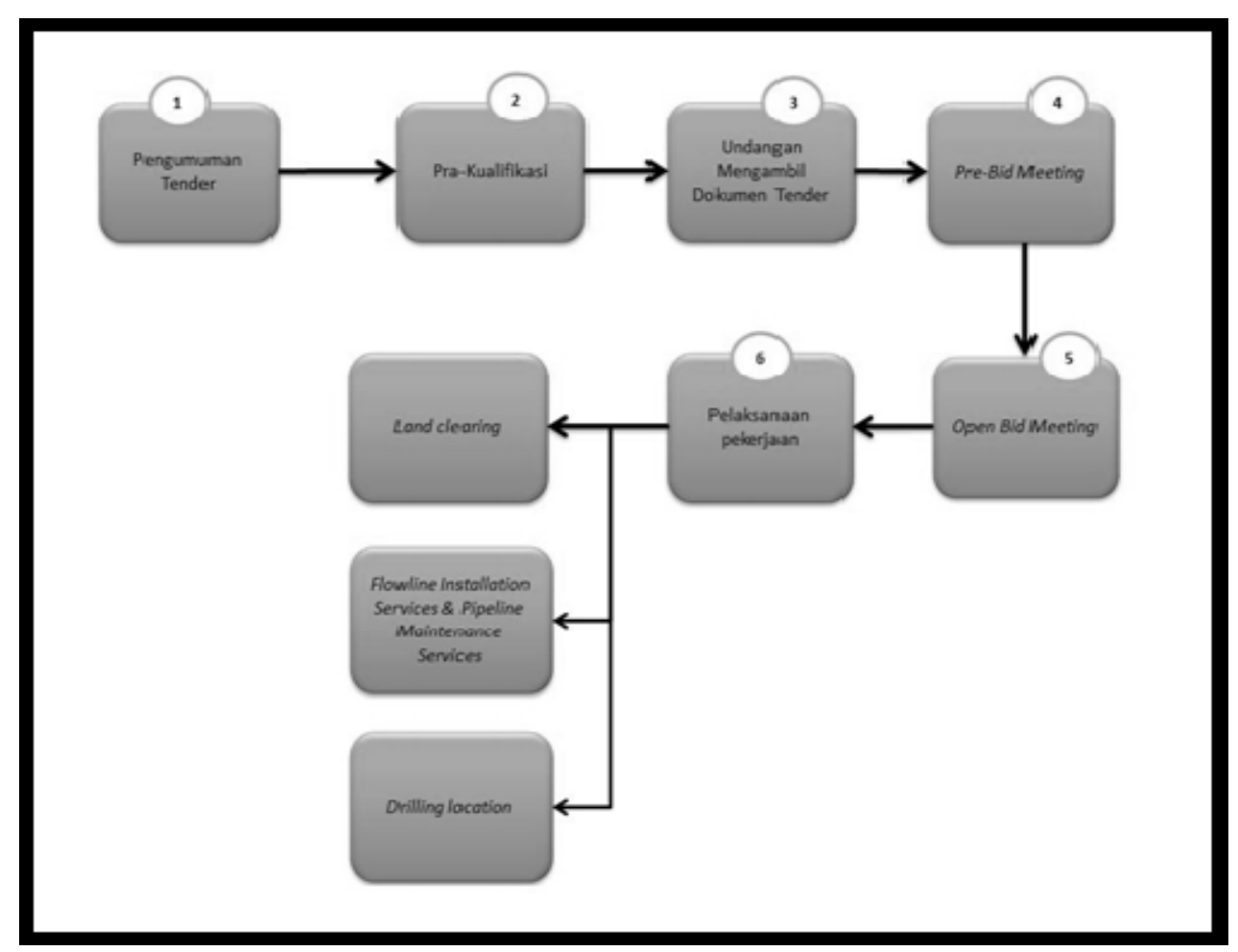

sumber : Data diolah

Gambar 3.

Proses Bisnis 
Gambar 3. merupakan gambaran dari proses bisnis dari PKP untuk mengidentifikasi risiko operasional.

\subsubsection{Hasil Asesmen Risiko Operasional}

Terdapat 9 risiko operasional yang teridentifikasi sebagai risiko tertinggi PKP, yaitu yang berada di sebelah luar garis risk tolerance (Gambar 4.):

1. Pekerjaan tidak selesai pada jadwal yang ditentukan.

Status risiko berjumlah 12 . Risiko ini mungkin terjadi jika PKP melakukan estimasi dalam menentukan jadwal pekerjaan kurang realistis.

2. Keterlambatan alat tiba dilokasi.

Status risiko berjumlah 12 . Risiko ini dapat terjadi pada pelaksanaan pekerjaan yang biasanya karena disebabkan oleh beberapa alasan seperti traffic accident (kecelakaan saat alat diangkut ke lokasi), akses menuju lokasi jauh, atau bahkan kapal pengangkut terbakar.

3. Unit break down.

Status risiko berjumlah 12 . Risiko ini dapat terjadi pada pelaksanaan pekerjaan yang biasanya karena terlambat penyediaan spare part, periodik perawatan tidak sesuai jadwal dan spare part alat berat dicuri oleh masyarakat lokal.

4. Tidak tersedia cadangan BBM atau habis. Status risiko berjumlah 12 . Risiko ini dapat terjadi pada pelaksanaan pekerjaan karena keterlambatan pembayaran supplier.

5. Pekerja diusir oleh penduduk lokal.

Status risiko berjumlah 12 . Pada pelaksanaan pekerjaan flowline installation services \& pipeline maintenance services,sering terjadi penduduk lokal memaksa dipekerjakan dalam proyek ada di lokasi tersebut, jika tidak dipatuhi tuntutan tersebut makan dapat diusir oleh penduduk lokal.

6. Kekurangan tenaga kerja.

Status risiko berjumlah 9. Risiko ini mungkin terjadi ketika ada karyawan yang sakit atau sekedar tidak masuk kerja, sedangkan tenaga kerja pengganti harus sesuai dengan persyaratan yang dibutuhkan.

7. Letak pipa bergeser.

Status risiko berjumlah 9. Pada pelaksanaan flowline installation services \& pipeline maintenance services, dapat terjadi pergeseran pipa, yang biasanya disebabkan karena terjadi tanah longsor di lokasi pipa dipasang.

8. Proyek terlambat.

Status risiko berjumlah 12 . Risiko ini mungkin sekali terjadi ketika sedang dalam musim hujan, karena walaupun hanya cuaca mendung, pekerjaan tidak dapat dilakukan karena jarak pandang menjadi berkurang dan berbahaya.

9. Kecelakaan kerja.

Status risiko berjumlah 16 . Pada peta risiko, risiko ini berada pada wilayah berwarna merah, karena jika terjadi kecelakaan kerja, proyek akan dihentikan beberapa menit ataupun beberapa hari yang akan sangat mempengaruhi jalannya proyek. Risiko ini disebabkan karena pekerja mengabaikan HSE Induction. 


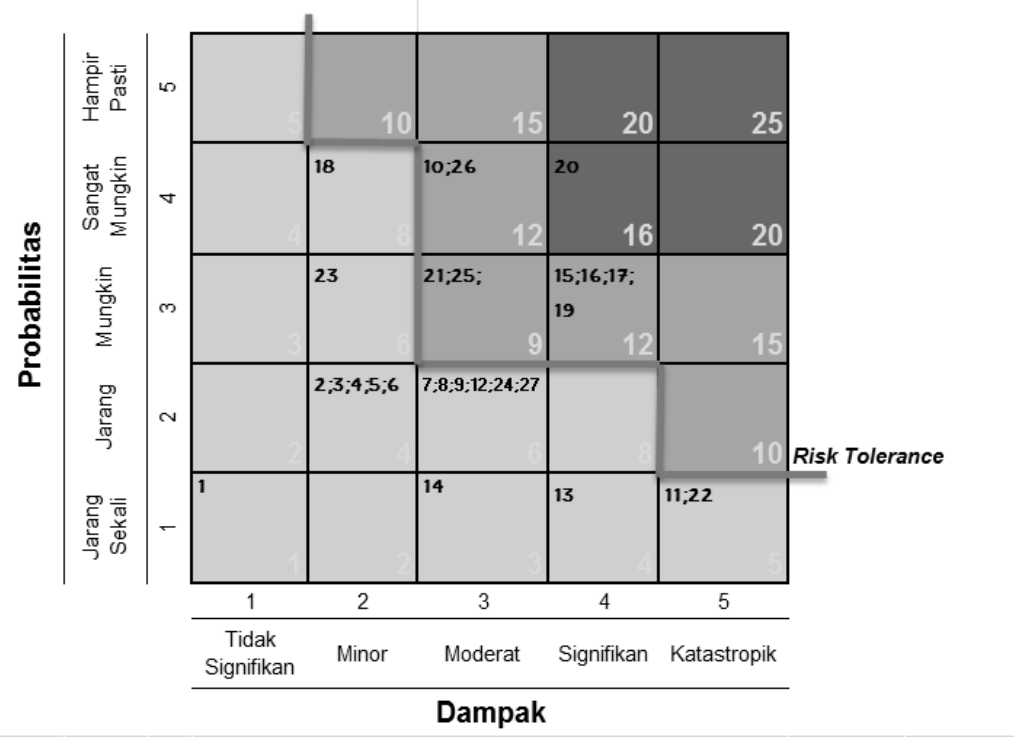

sumber : Data diolah

Gambar 4.

Peringkat Risiko Operasional

4.3 Hasil Asesmen Risiko Kesehatan Kecelakaan Kerja (K3)

Terdapat 5 risiko keselamatan kesehatan kerja yang teridentifikasi sebagai risiko tertinggi $\mathrm{PKP}$, yaitu risiko high level yang berada pada wilayah merah (Gambar 5.):

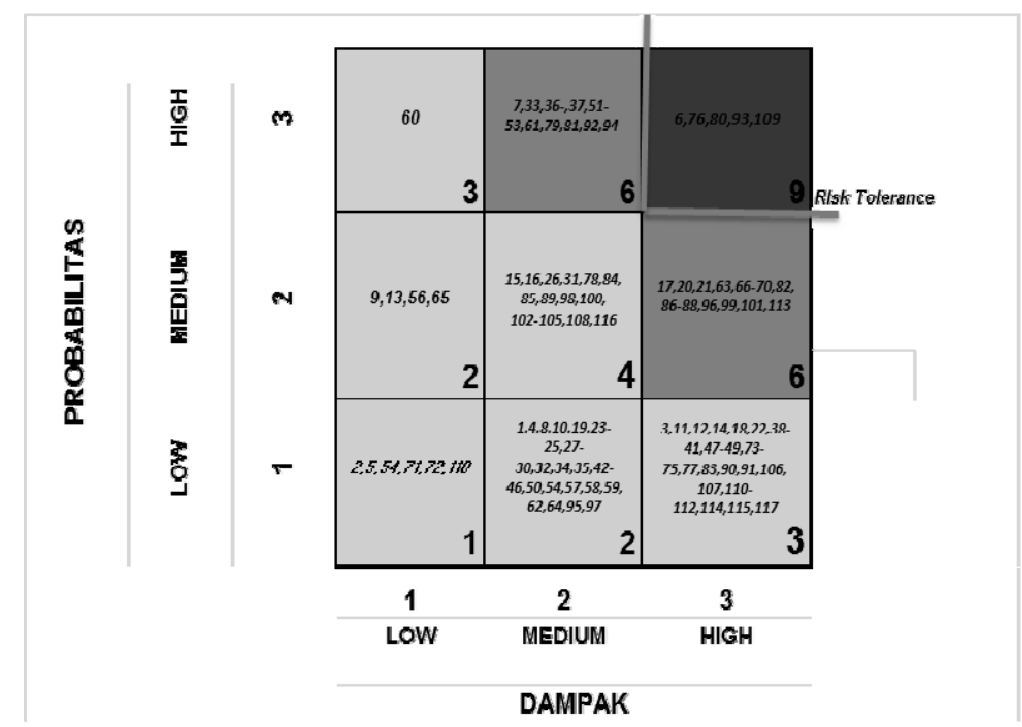

sumber : Data diolah

Gambar 5.

Peringkat Risiko Keselamatan Kesehatan Kerja 
1. Kejang/meninggal.

Risiko kejang atau bahkan meninggal pada pekerjaan civil work / survey dapat terjadi jika karyawan terpatok ular.

2. Cedera, pingsan, kematian dan kerugian aset.

Pada pekerjaan welding, grinding \& hot cutting, dapat terjadi kebakaran yang akan menyebabkan karyawan cedera, pingsan bahkan kematian dan tentu saja akan mengalami kerugian aset.

3. Merusak paru-paru dan sesak napas.

Risiko ini juga dapat terjadi pada pekerjaan welding, grinding \& hot cutting karena adanya asap las yang dapat dihirup oleh karyawan.

4. Merusak lingkungan.

Jika ada kejadian oil spill pada pekerjaan cold cutting \& tie in, tidak menutup kemungkinan akan terjadi perusakan lingkungan yang akan merugikan masyarakat sekitar.

5. Pencemaran lingkungan/tanah.

Risiko ini dapat saja terjadi pada saat pekerjaan panas dilakukan, jika terjadi tumpahan minyak atau solar, maka akan mencemarkan lingkungan atau keadaan tanah yang akan mempengaruhi keberadaan perusahaan.

\subsection{Rencana Pengelolaan Risiko Operasional}

Risiko dengan area kritis menyusun schedule pekerjaan yaitu pekerjaan tidak selesai pada jadwal yang ditentukan dengan respon risiko yang dipilih adalah mitigation, mengurangi risiko dengan cara membuat sistem manajemen waktu proyek, maka kegiatan pengelolaan risiko tersebut yaitu:

1. Menentukan penjadwalan proyek.

2. Mengukur dan membuat laporan dari kemajuan proyek.

3. Membandingkan penjadwalan dengan kemajuan proyek sebenarnya di lapangan.
4. Menentukan akibat yang ditimbulkan oleh perbandingan jadwal dengan kemajuan di lapangan pada akhir penyelesaian proyek.

5. Merencanakan penanganan untuk mengatasi akibat tersebut.

6. Memperbaharui kembali penjadwalan proyek.

Risiko dengan area kritis mobilisasi alat berat yaitu keterlambatan alat tiba dilokasi dengan respon risiko yang dipilih adalah mitigation, mengurangi risiko dengan dua cara:

1. Menjadwalkan pengiriman alat lebih awal berdasarkan skala prioritas, maka kegiatan pengelolaan risiko tersebut yaitu:

a. Bekerja sama dan menjalin hubungan dan komunikasi yang baik dengan supplier yang siap mengirim alat tepat waktu sesuai kesepakatan kedua belah pihak.

b. Membuat material loading.

2. Membuat Rambu-rambu dan perbaikan jalan, kegiatan pengelolaan risiko tersebut yaitu:

a. Memberikan rambu-rambu di jalan yang dilintasi kendaraan proyek.

b. Melakukan perawatan terhadap jalan yang selalu dilintasi oleh kendaraan proyek.

Risiko unit break down dengan dua respon risiko mitigation, mengurangi risiko dengan tiga cara:

1. Melakukan preventive maintenance dengan kegiatan pengelolaan:

a. Periodik maintenance sesuai schedule atau dalam jangka waktu tertentu, misalnya setiap satu minggu sekali.

b. Melakukan inspeksi alat sebelum dikirim ke lapangan.

c. Mempercepat pengadaan sparepart.

2. Seleksi pengadaan dan standarisasi, dengan kegiatan pengelolaan yaitu melakukan pertimbangan membeli atau menyewa. 
3. Memberikan pelatihan kepada tenaga kerja dengan kegiatan pengelolaan yaitu dengan mengadakan pelatihan-pelatihan, pengajaran dan penjelasan mengenai peralatan serta metode konstruksi

Dan untuk respon risiko transfer, memindahkan risiko dengan menggunakan jasa asuransi pada kegiatan pengiriman material dan equipment.

Risiko tidak tersedia cadangan $\mathrm{BBM} /$ habis dengan respon risiko mitigation, mengurangi risiko dengan dua cara:

1. Melakukan pembayaran tepat waktu, kegiatan pengelolaan risiko tersebut yaitu:

a. Menyegerakan pelunasan kepada supplier.

b. Bekerja sama dan menjalin hubungan dan komunikasi yang baik dengan supplier.

2. Melakukan kerja sama dengan lebih dari satu supplier, kegiatan pengelolaan risiko tersebut yaitu dengan mengatur jadwal pengiriman BBM antara supplier yang dimiliki agar dapat segera mengirimkan pasokan BBM.

Risiko dengan area kritis personnel preparedness yaitu pekerja diusir oleh penduduk lokal dengan respon risiko mitigation, mengurangi risiko dengan cara melakukan sosialisasi sebelum melaksanakan proyek dengan kegiatan melakukan serangkaian pendekatan dan komunikasi dengan melibatkan tokoh masyarakat dan merekrut penduduk lokal.

Risiko kecelakaan kerja dengan respon risiko mitigation, mengurangi risiko dengan meningkatkan kesadaran tentang K3 dan prosedur Kerja yang telah ditetapkan. Dan kegiatannya yaitu:

1. Memberikan HSE Induction untuk setiap orang yang bekerja, survey atau berkunjung ke area konstruksi.
2. Memberikan briefing safety setiap hari sebelum melaksanakan pekerjaan.

Risiko kekurangan tenaga kerja dengan respon risiko mitigation, mengurangi risiko dengan melakukan perencanaan pengisian personil (Staffing plan). Dan kegiatannya yaitu melakukan pengadaan Sumber Daya Manusia sesuai dengan kebutuhan proyek, dalam arti jumlah, kualitas dan jadwalnya.

Risiko dengan area kritis execution pada pekerjaan flowline yaitu letak pipa bergeser dengan respon risiko mitigation, mengurangi risiko dengan cara melakukan penyelidikan dan pemetaan risiko geologi teknik secara tepat dengan kegiatan penyelidikan dilakukan secara tepat dan teliti, pemetaan dan antisipasi risiko geologi teknik.

Risiko dengan area kritis suhu di permukaan yaitu proyek terlambat dengan respon risiko acceptance, menerima risiko namun tidak hanya diam saja melainkan tetap memonitor prakiraan cuaca dari BMKG dengan kegiatan membuat laporan prakiraan cuaca sebagai acuan.

\subsection{Pemetaan Risiko Operasional}

Setelah dilakukan respon dan pengelolaan pada risiko-risiko tersebut, maka terjadi perubahan pada peta risiko berikut ini (Gambar 6.).

Dapat terlihat adanya perubahan kategori dari kategori risiko-risiko yang sebelumnya dengan gambar di bawah, dimana setelah dilakukan respon dan pengelolaan seluruh risiko yang telah teridentifikasi tersebut berada pada kategori low dan medium (toleransi risiko yang telah ditetapkan BOD). 


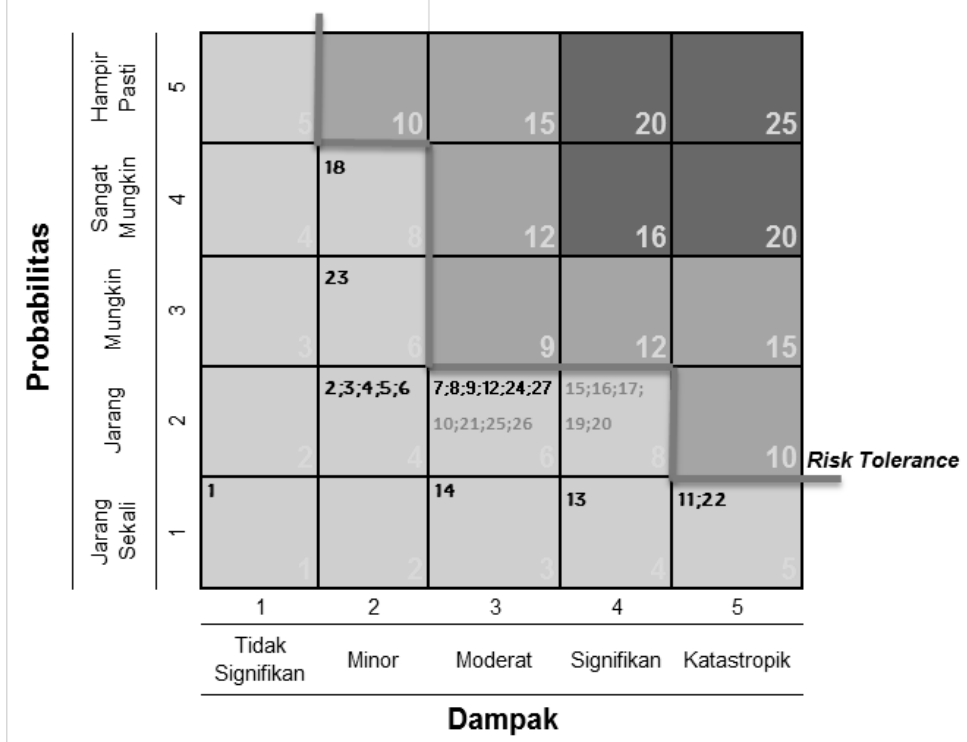

Gambar 6.

Peringkat Risiko Operasional Setelah Pengendalian

\subsection{Pengelolaan Risiko K3}

Setelah dilakukan respon dan pengelolaan pada risiko-risiko tersebut, maka terjadi perubahan pada peta risiko berikut ini (Gambar 7.):

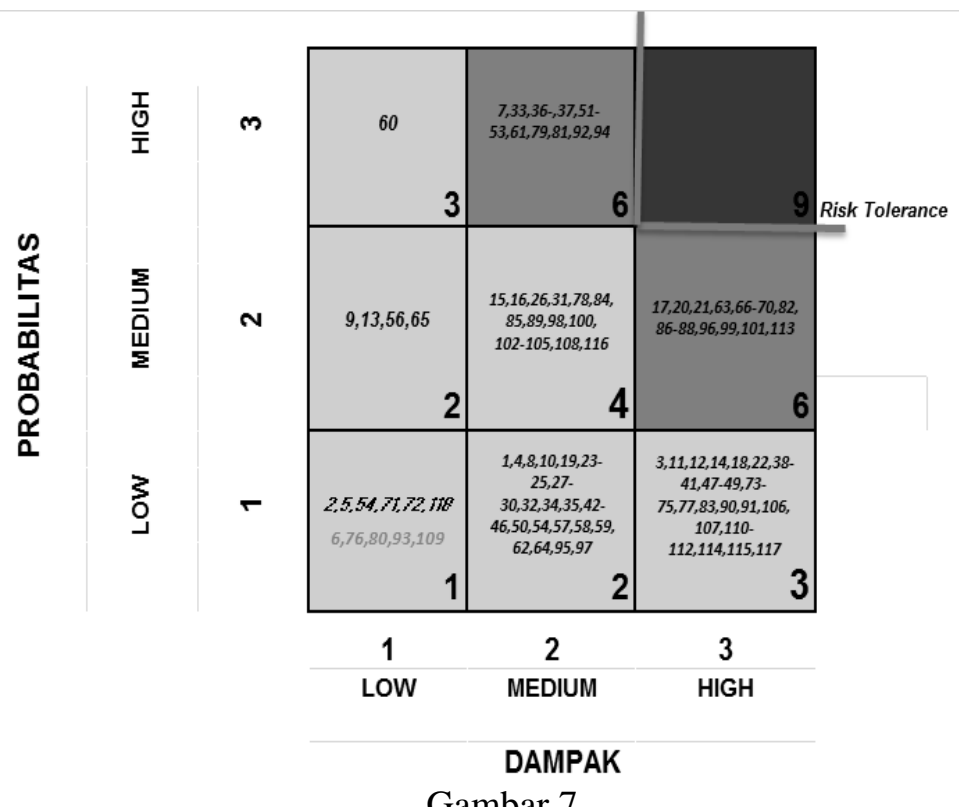

Peringkat Risiko K3 Setelah Pengendalian 
Dapat terlihat adanya perubahan kategori dari kategori risiko-risiko yang sebelumnya dengan gambar di atas, dimana setelah dilakukan respon dan pengelolaan seluruh risiko yang telah teridentifikasi tersebut berada pada kategori low dan medium (toleransi risiko yang telah ditetapkan BOD).

\subsection{Tahapan Implementasi Manajemen Risiko}

Setelah divisi manajemen risiko dibentuk, maka rencana kerja yang dilaksanakan adalah sebagai berikut:

1. Tahap Pertama

Melakukan identifikasi risiko baik yang telah terjadi maupun yang mungkin akan terjadi, melakukan analisis dampak, melakukan evaluasi sebagai bandingan hasil analisis risiko dengan kriteria risiko, untuk menentukan tingkat risiko tersebut dapat diterima, ditoleransi, atau ditolak.

2. Tahap Kedua

Memutuskan tindakan yang dipilih untuk merespon risiko, yaitu menghindar (avoidance), menerima (acceptance), mengurangi (mitigation), atau mengalihkan (transfer risk). Membuat suatu kegiatan pengendalian risiko untuk diterapkan pada PKP.

3. Tahap Ketiga

Melakukan monitoring perubahan risiko dan melakukan revisi perlakuan risiko, atau bahkan perubahan prioritas risiko.

\subsection{Pelaksanaan Monitoring}

Monitoring bertujuan untuk menunjang dan meningkatkan pelaksanaan tata kelola manajemen risiko secara berkelanjutan. Adapun tindakan-tindakan yang akan dilakukan adalah sebagai berikut:

1. Adanya pendidikan dan pelatihan berlanjut mengenai manajemen risiko bagi para pemangku risiko langsung, yaitu Manajer di masing-masing divisi.
Diharapkan setelah mengikuti pelatihan mengenai manajemen risiko, para pemangku risiko dapat memberikan pengetahuannya kepada para staf dalam divisinya masing-masing dengan tujuan meningkatkan pemahaman mengenai pentingnya manajemen risiko.

2. Adanya review dalam penerapan manajemen risiko yang dilakukan. Dengan adanya review, diharapkan PKP dapat memperbaiki kekurangankekurangan dalam penerapan manajemen risiko yang dilakukan. Selain review, PKP juga diharapkan melakukan benchmarking atau perbandingan kepada perusahaan jasa konstruksi sejenis lain yang sudah menerapkan manajemen risiko.

3. Hasil monitoring dan review harus didokumentasikan dengan baik serta sesuai dengan kebutuhan. Harus juga dilaporkan. Pelaporan hasil monitoring dan review secara keseluruhan menjadi tanggung jawab dari fungsi manajemen risiko. Akan tetapi, laporan untuk pelaksanaan pemantauan berlanjut dan berkala berada pada masing-masing unit kerja. Laporan hasil monitoring dan review bertujuan untuk memastikan bahwa proses manajemen risiko memang memenuhi sasaran yang ditetapkan, atau mengidentifikasikan kelemahan yang masih ada sehingga dapat dilakukan perbaikan sebagaimana mestinya. Dimana pelaksanaannya, yaitu:

a. Evaluasi penerapan manajemen risiko harus dilaksanakan minimal satu kali dalam satu tahun. Evaluasi ini untuk memeriksa efektifitas, tingkat kematangan penerapan manajemen risiko, dan kinerja manajemen risiko sesuai dengan tujuan pembentukannya;

b. Laporan fungsi manajemen risiko setiap triwulan terhadap Direktur dengan tembusan ke Dewan Komisaris 
atas: status profil risiko perusahaan terkini dan kecenderungannya (trend); efektifitas pengendalian risiko-risiko besar dan risiko-risiko kritis; hasil mitigasi-mitigasi risiko yang dilakukan dalam periode laporan tersebut; perubahan lingkungan eksternal dan internal yang mempunyai potensi risiko bagi perusahaan; dan observasi kemampuan para Risk Owners dalam perusahaan dalam menangani risikorisiko yang menjadi tanggung jawabnya.

4. Dokumentasi Manajemen Risiko. Dokumentasi suatu proses manajemen secara umum mempunyai tiga macam fungsi, yaitu:

a. Rekaman proses pelaksanaan kegiatan yang sekaligus menjadi sumber informasi atas proses yang terjadi dan dapat menjadi dasar pengambilan keputusan untuk masalah yang sama di masa depan;

b. Menjadi bukti hukum atas apa yang telah diputuskan dan dilaksanakan, khususnya bila terjadi sengketa hukum;

c. Sarana untuk preservasi pengetahuan sebagai bagian dari proses pengembangan knowledge management dalam suatu organisasi.

5. Adanya proses komunikasi yang secara terus menerus dilakukan oleh PKP, tidak hanya pada saat tahapan awal dalam penerapan manajemen risiko yang dilakukan. Proses komunikasi yang dilakukan secara terus menerus dilakukan agar kesadaran dalam penerapan manajemen risiko akan terus tumbuh bagi pihak internal PKP serta agar PKP selalu mendapatkan dukungan dari stakeholder dalam implementasi manajemen risiko.

\section{KESIMPULAN}

Berdasarkan hasil evaluasi yang telah dilakukan terhadap proses manajemen risiko operasional pada PKP maka dapat diperoleh beberapa kesimpulan, antara lain:

1. Berdasarkan kuesioner yang disebarkan untuk mengetahui tingkat maturity dalam penerapan manajemen risiko, diketahui bahwa pengalaman (experience) manajemen risiko pada PKP dapat dikatakan paling minim jika dibandingkan dengan faktor-faktor lainnya yang terdapat dalam kuesioner. Hasil penilaian pada PKP yang minim terhadap pengalaman manajemen risiko didukung oleh belum adanya bentuk aplikasi manajemen risiko di PKP sendiri. Tetapi di satu sisi, faktor yang mendapat nilai tertinggi dalam hasil kuesioner ini adalah culture. Hal ini dapat menandakan bahwa PKP sudah memiliki pemahaman mengenai perlunya penerapan manajemen risiko, yang ditandai dengan mulai tumbuhnya kesadaran pihak PKP, mengenai perlunya penerapan manajemen risiko.mengenai risiko-risiko yang dapat muncul dalam pekerjaan yang dilakukan, serta adanya dukungan dalam pemahaman konsep manajemen risiko di PKP.

2. Telah dilakukan risk assesment pada PKP dengan hasil sebagai berikut:

a. Risiko Operasional

- Kejadian risiko yang teridentifikasi sebanyak 27 risiko. Dari total tersebut terdiri dari 17 risiko kategori low; 9 risiko kategori medium; 1 risiko kategori high.

- Terdapat 9 risiko operasional yang teridentifikasi sebagai risiko tertinggi PKP, yaitu yang berada di sebelah luar garis biru (risk tolerance) dan diperlukan penanganan lebih lanjut dengan membuat rencana penanganan risiko. 
b. Risiko K3

- Kejadian risiko K3 yang teridentifikasi sebanyak 118 risiko. Dari total tersebut terdiri dari 84 risiko kategori low; 29 risiko kategori medium; 5 risiko kategori high.

- Terdapat 5 risiko K3 yang teridentifikasi sebagai risiko $\mathrm{K} 3$ tertinggi PKP, yaitu yang berada di sebelah luar garis biru (risk tolerance) dan diperlukan penanganan lebih lanjut dengan membuat rencana penanganan risiko.

3. Dalam perancangan sistem manajemen risiko PKP, tidak dilakukan penambahan sumber daya manusia yang ditujukan khusus untuk menangani risiko yang ada. Namun dilakukan perekrutan dari internal perusahaan dengan merekrut dari setiap divisi yang ada. Setelah perekrutan, membuat jadwal pelatihan karyawan. Penjadwalan pelatihan karyawan mengikutsertakan divisi-divisi lain sehingga pelatihan karyawan ini dapat disesuaikan dengan kebutuhan untuk mengurangi risiko-risiko yang ada di PKP yang disebabkan oleh karyawan yang kurang kompeten.

4. Sistem pelaporan Divisi manajemen risiko langsung kepada Direktur Utama PKP. Dengan adanya struktur yang baru diharapkan pengambilan keputusan menjadi lebih cepat dan efektif. Hal ini dikarenakan Divisi manajemen risiko memiliki keterbatasan otoritas pada pemberian laporan dan pemberian saran dalam identifikasi dan pengelolaan risiko, namun keputusan akhir untuk menolak, menerima, atau mentolerir tetap pada Direktur Utama.

5. Isi laporan yang akan disampaikan kepada

Direktur berisikan mengenai hasil dari kegiatan monitoring dan review serta ringkasan akhir yang dilakukan oleh pihak-pihak yang bertanggung jawab langsung terhadap kegiatan tersebut. 
Model Pengelolaan dan ... (Eva P. P. dan Martin R. P. H.)

\section{DAFTAR PUSTAKA}

Berita Resmi Badan Pusat Statistik No. 13/02/Th. XV, 6. F. 2012. Berita Resmi Badan Pusat Statistik . No. 13/02/Th. XV.

Djohanputro, B. 2008. Manajemen Risiko Korporat. Jakarta: Penerbit PPM.

Dr. Mamduh M. Hanafi, M. 2006. Manajemen Risiko. Yogyakarta: UPP STIM YKPN.

Kountur, R. 2004. Manajemen Risiko Operasional: Memahami Cara Mengelola Risiko Operasional Perusahaan. Jakarta: PPM.

Leo J. dan Susilo V. R. 2010. Manajemen Risiko Berbasis ISO 31000 Untuk Industri Non - Perbankan. Jakarta: PPM.

Outlook Ekonomi Indonesia 2008 - 2012. Outlook Ekonomi Indonesia 2008 - 2012.

Ramli, S. 2010. Pedoman Praktis Manajemen Risiko dalam Perspektif K3 OHS Risk Management. Jakarta: Dian Rakyat.

Siahaan, H. 2007. Manajemen Risiko: Konsep, Kasus, dan Implementasi. Jakarta: PT. Elex Media Komputindo. 